\title{
Revisiting Urbanisation Pattern amid COVID-19 Pandemic in India
}

\author{
Hemant Patidar ${ }^{+*}$ and Satheesh Chothodi ${ }^{\dagger}$
}

\section{Abstract}

The COVID-19 pandemic, from its beginning in India on 30 January 2020, has caused over 3.7 million cases of illness and claimed over 66 thousand deaths as of 1 September2020. The large metropolitan cities have been the major hotspots of COVID-19 pandemic. The peculiar urbanisation patterns are crucial in spreading COVID-19 in India. This study attempts to highlight how urbanisation patterns increase the vulnerability of COVID-19 spread in India. The higher density, urban sprawl and associated intra-urban commuting, large slum population, inadequate water, sanitation and housing conditions along with homelessness are found to catalyse the vulnerability of COVID-19 spread in urban areas. The existing public health infrastructure in the country is found to be inadequate with respect to the increasing demand. Efforts to contain the spread are being made; nonetheless, the rapid increase in the cases of illness and deaths from COVID-19 has inflated the challenges for administration and citizens. Rapid enhancement in health infrastructure and health personnel must be made along with strict adherence to the measures of quarantine, social distancing and hygiene for the citizens are of utmost response to the decrease the spread.

Keywords: Urbanisation; COVID-19; Population Density; Migrant Workers; Health Infrastructure; India

\footnotetext{
${ }^{+}$Assistant Professor, Department of General \& Applied Geography, School of Applied Sciences, Doctor Harisingh Gour Vishwavidyalaya Sagar, Madhya Pradesh, 470003

${ }^{*}$ Corresponding Author, Email: drhemantpatidar@gmail.com

(C) 2020 Patidar \& Chothodi. This is an Open Access article distributed under the terms of the Creative Commons Attribution License (http://creativecommons.org/licenses/by/2.0), which permits unrestricted use, distribution, and reproduction in any medium, provided the original work is properly cited.
} 


\section{Introduction}

The world is undergoing a ruthless experience of severe acute respiratory syndrome-Coronavirus 2 (SARS-CoV-2) pandemic, which has caused over 26 million cases of illness and claimed over 0.86 million deaths as of 1 September 2020 spreading in 216 countries (WHO, 2020). The interventions such as massive lockdowns, quarantine, social distancing, contact tracing, rapid testing and hygiene awareness by governments all across the countries, notwithstanding, the number of cases of illness and resulting death from COVID-19 is increasing in the absence of any apt pharmaceutical solution till date. Global evidence reveals that the emergence of such pathogens and their subsequent spread significantly draw a drastic impact on global health and economies (Jones et al. 2008; McLafferty, 2010; Morens et al., 2004; Smolinski et al., 2003). The emergence of many infectious diseases is found to be the outcome of anthropogenic and demographic changes and is the hidden cost of human economic development (Daszak et al., 2000; Jones et al., 2008; Weiss \& McMichael, 2004). Indeed, Jones et al. (2008) found that human population, in addition to the environmental (latitude, rainfall) and ecological variable (wildlife host species richness), is a common significant independent predictor in the emergence of 335 infectious diseases (EIDs) between 1940 and 2004.

The global population is rapidly urbanised (Zachreson et al., 2018) as 56 per cent (4.2 billion) of the world population lives in urban areas (United Nations, 2018). Urbanisation is often linked to economic development, increased access to education, health care, social services and enhanced quality of life. According to the World Bank, (2020), more than 80 per cent of the global GDP is generated in cities. However, rapid urbanisation also brings several challenges of clean water, sewage and sanitation, housing, public health services and unemployment. Global evidence suggest that the urban areas due to high population densities are the potential hotspots in terms of disease transmission (Acuto, M. 2020; Barr \& Tassier, 2020; Biswas, 2020; Desai, 2020; Hotez, 2017; Jha, 2020; Neiderud, 2015; Rocklöv \& Sjodin 2020; Sundaram et al., 2014; Zachreson et al., 2018). In developing countries, higher density living conditions, poverty and poor sanitation worsen the epidemic mainly in urban areas (Zachreson et al., 2018). In view of the global shreds of evidence confirming the association between urbanisation and the spread of infectious disease transmission, this study attempts to highlight how the urban characteristics increase the vulnerability of COVID-19 spread in India. In this article, the six characteristics of urban India which have been associated with increasing the vulnerability of Covid-19 in the large urban centres and its trickle-down into rural India have been theoretically discussed.

\section{Urbanisation Patterns and Vulnerability to COVID-19 in India}

India is the second-largest (1.37 billion people) and a highly dense populace (460 persons per sq. Km) (United Nations, 2019). India has been largely a rural and agrarian country, but after the economic liberalisation in 1990s rural to urban migration increased, resulting in rapid urbanisation (Table 1). Nevertheless, the total urban population (377.1 billion in 2011), which accounts for 31.16 per cent of the total population itself is higher than the population of any country in the world except for China. In India, the urbanisation pattern has been skewed in terms of the growth of metropolitan cities. Until 1941, India had only two cities with one million population that increased to 53 in 2011 (Table 1). The share of the population of metropolitan cities out of the total urban population increased more than seven times, from 5.8 per cent in 1901 to 42.3 per cent in 2011 (Table 1). Due to the high concentration of economic activities in metro cities, migrant workers were (and continue) to be attracted to these cities. Urban growth in India is also found to be predominantly unplanned and marketdriven (Biswas, 2020). 


\begin{tabular}{|c|c|c|c|c|c|c|}
\hline Year & $\begin{array}{l}\text { Urban } \\
\text { Population } \\
\text { (In Million) }\end{array}$ & $\begin{array}{l}\text { Percentage } \\
\text { of urban } \\
\text { population } \\
\text { to total } \\
\text { population }\end{array}$ & $\begin{array}{l}\text { Number of } \\
\text { Class I Cities } \\
\text { (Population } \\
\text { One Lakh \& } \\
\text { above) }\end{array}$ & $\begin{array}{l}\text { Metropolitan } \\
\text { cities } \\
\text { (Population } \\
\text { One Million } \\
\text { \& above) }\end{array}$ & $\begin{array}{l}\text { Population in } \\
\text { metropolitan } \\
\text { cities to } \\
\text { India's total } \\
\text { population } \\
\text { (In Per cent) }\end{array}$ & $\begin{array}{l}\text { Population } \\
\text { of } \\
\text { metropolitan } \\
\text { cities out of } \\
\text { total urban } \\
\text { population } \\
\text { (In Per cent) }\end{array}$ \\
\hline 1901 & 25.8 & 10.83 & 24 & 1 & 0.6 & 5.8 \\
\hline 1911 & 25.9 & 10.27 & 23 & 2 & 1.1 & 10.7 \\
\hline 1921 & 28.1 & 11.18 & 29 & 2 & 1.3 & 11.1 \\
\hline 1931 & 33.5 & 12.01 & 35 & 2 & 1.2 & 10.2 \\
\hline 1941 & 44.2 & 13.87 & 49 & 2 & 1.7 & 12.0 \\
\hline 1951 & 62.4 & 17.29 & 76 & 5 & 3.3 & 18.8 \\
\hline 1961 & 78.9 & 17.96 & 102 & 7 & 4.1 & 22.9 \\
\hline 1971 & 109.1 & 19.91 & 148 & 9 & 5.1 & 25.5 \\
\hline 1981 & 159.4 & 23.33 & 216 & 12 & 6.2 & 26.4 \\
\hline 1991 & 217.6 & 25.71 & 296 & 23 & 8.4 & 32.5 \\
\hline 2001 & 285.4 & 27.78 & 441 & 35 & 10.5 & 37.9 \\
\hline 2011 & 377.1 & 31.16 & 468 & 53 & 13.2 & 42.3 \\
\hline
\end{tabular}

Evidence suggest that India's peculiar urbanisation pattern is of particular attention for the emergence and spread of viruses posing significant pandemic threats (Gani et al., 2011; Kumar \& Quinn, 2012).

\section{Population Density}

Unlike in most developing countries, India's urbanisation is characterised by an unusually large number of highly populated cities (Jonathan, 2017). The high density of population increases the chances of contacts with diseased persons (Ruiqi et al., 2018) and consequently, the dense urban centres have been the hotspots of COVID-19 cases (Biswas, 2020; Desai, 2020; Joel, 2020; Rocklöv \& Sjodin, 2020). In the dense areas, an infected person may pass on the illness to others throughout his/her infection due to practical difficulty in isolation and social distancing measures. Several mega-urban centres, notably New York, London, Madrid, Tehran, Mumbai, Delhi, Milan, São Paulo, etc. are the dense megacities and have recorded maximum COVID-19 cases and resultant deaths. The top nine urban agglomerations in India, which collectively accounts 7.41 per cent of the country's total population (GOI, 2011), have recorded nearly 48 per cent of total COVID-19 cases (743481) and 62 per cent (20653) of the total deceased in the country until 8 July 2020 (Table 2). Delhi's Jahangirpuri, Mumbai's Dharavi and Koyambedu Market of Chennai, being dense areas, have recorded a large number of COVID19 cases and resultant deaths in the respective cities. The size and density of population in India cities are of grave concern amid the pandemic. 


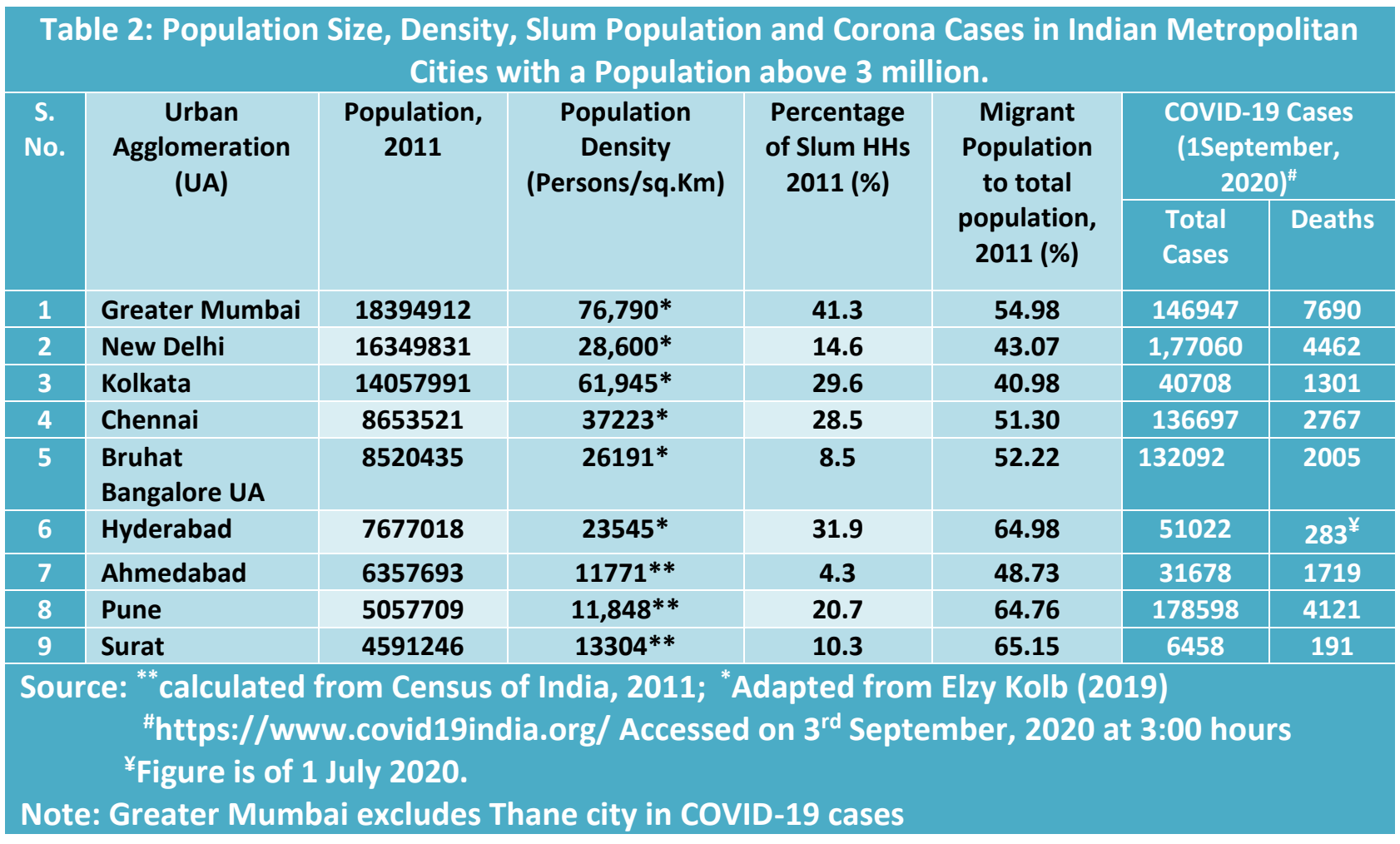

\section{Urban Sprawl and Commuting}

Urban sprawl, the geographic expansion of cities, is also a serious threat of the further spread of the disease through the long intra-city transport networks. The intra-urban and suburban transport connectivity allows people to commute between their place of residence and work. This frequent and large scale intra-city commuting increases the likelihood of the spread of disease in various pockets of a city. In respect to the communicable disease, the concentration of the workforce in Central Business Districts (CBDs), industrial hubs, slums and suburban sprawl increase the interaction and contacts that could potentially lead to proliferating the infectious disease between work and home (Eubank, et al., 2004; Yashima \& Sasaki, 2014). Moreover, industrial units, over congested vehicular movement and lack of greenery in urban areas lead to air pollution in large cities that further weakens lung function and increase the vulnerability of COVID-19 (Xiao et al., 2020). Indian cities like Mumbai, Kolkata and Delhi have nearly 7 million, 4 million and 2.5 million passengers, respectively, who commute from suburbs to CBDs daily using local train services (Biswas, 2020). The passenger density in metro and local trains and sub-urban mainline electric multiple unit (MEMU) trains is much higher than the recommended density and increase the chances of infection. Many often urban regulatory bodies attempt to offset the increased passenger mobility by increasing vehicular density, but this situation further worsens the urban traffic as the major routes in cities connecting different urban pockets get saturated during peak hours. In the top 100 Indian cities vehicle ownership grew by seven times in the past 20 years at a compound annual rate of 10 per cent (Guttikunda \& Mohan, 2014). The increased over route traffic and congestion increase the journey time, which enhances the potency of the virus to pass on to other people.

\section{Slums and Homelessness}

In the lower and middle-income countries, the movement of people from rural to urban areas in search for employment leads to the expansion of urban agglomerations (Pradhan, 2013) and development of the concentrated residential crowding that is slums which are often characterised by the exposure to environmental hazards (Wratten, 1995). The slum is a contiguous settlement where the inhabitants are characterised as having inadequate housing and basic services according to the United 
Nations Program on Human Settlements (UNHabitat, 2003). Nearly 5.41 per cent (65.49 million) of India's total population (GOI, 2011) live in an estimated 33,510 slums in India (GOI, 2014). Nearly half of all residents in large urban agglomeration live in extremely dilapidated slums (Table 2). In many cases, slum residents have been found waiting to use public toilets and immense time for procuring water and other resources (Subbaraman et al., 2014), which tend to promote the transmission of infectious diseases like pneumonia, diarrhoea and tuberculosis (Unger \& Riley, 2007). Asia's largest Slum that is Mumbai's Dharavi, for instance, has a population of 0.8 million living in a total area of $2.1 \mathrm{sq}$. Km with a density of 354,167 persons per sq. Km (Desai, 2020; Hindustan Times, 2020). It has emerged as a major hotspot of COVID-19 cases due to its high density of population.

The $69^{\text {th }}$ round of National Sample Survey (NSS) report on Housing conditions reveals that the poorest 60 per cent of the urban population has just 380 square feet built-up area per family (GOI, 2014). Around 17.4 per cent (13.7 million) of total urban households live in informal settlements (GOI, 2011) and 938 thousand of country's total 1.7 million homeless population are found in urban areas (GOI, 2011). Moreover, the figures of the homeless population in urban areas are underreported, and urban homeless population can be extrapolated to be over 3 million in 2011 (Jena, 2017; Mitra 2020; Shaikh \& Singh, 2019; The Daily Pao, 2016). In the absence of house and adequate housing space, contacts within family and neighbourhood are an obvious outcome, and the measures of home quarantine and social distancing appear less realistic. These apparent situations are critical in containing the spread of the virus in the urban areas.

\section{Water and Sanitation}

The adequate supply of water and sanitation is the human right (United Nation, 2010). The water supply of 135 litres per capita per day (LPCD) should be given for domestic water use in urban local bodies. However, as per the Central Public Health and Environmental Engineering Organisation (CPHEEO), average water supply in urban local bodies is 69.25 LPCD (Ali \& Dkhar,
2018).In the present crisis of COVID-19, the supply of water is essentially required in the housing premises in order to maintain the norms of social distancing and avoiding contacts with other people. Nonetheless, nearly 29 per cent households (HHs) in urban India and 47 per cent $\mathrm{HHs}$ in slum areas do not have access to water within the housing premises, and 8 per cent of $\mathrm{HHs}$ need to fetch water from more than 100 metres away from their HHs (GOI, 2011).

Most Indian cities, due to intermittent water supply, have a higher chance of having sewage influx in water supply pipelines (Singhal et al., 2020). The virus may potentially spread through faecal matter, although less evident, a concern in a country where a large portion of the wastewater goes untreated (Nova, 2020). According to the National Green Tribunal, an estimated 60 per cent of the sewage from urban areas is discharged untreated into water bodies (Nova, 2020). The poor water supply and sanitation situation in urban India, pose severe public health challenges in the ongoing pandemic.

\section{Migrant Workers and Urban-Rural Linkages}

In urban India, a considerable population share (47 per cent) is a migrant population (GOI, 2011). Migrant workers are considered to be the backbone of Indian economy. People from all Indian states, notably Uttar Pradesh (UP), Bihar, Jharkhand, Rajasthan, Madhya Pradesh (MP), due to high unemployment in rural areas, migrate towards the metropolis of Mumbai, New Delhi, Chennai, Kolkata, Ahmadabad, Surat, Bangalore and Hyderabad. Nearly 67 per cent of urban migrant labourers work in the informal sector (NSSO, 2012). Migration from rural areas to urban areas is largely a kind of distress migration (Dandekar, 2020).In rural India, slightly higher than half of the total households are livelihood insecure (Patidar, 2018), and in the absence of sustained livelihood in rural areas, seasonal migration happens (Jonathan, 2017). The rural-urban linkages and mobility are critical determinants of containing and mitigating the spread of infectious disease (Biswas, 2020). An estimated 20 to 25 million migrant workers returned to villages in trains, buses and on foot 
according to a report submitted to the Union Health Ministry by the Government's Rapid Response Team (RRT) (Sharma, 2020). The return of migrant workers, mainly from large metropolitan cities into villages, has triggered a fresh wave of infections in rural areas. In the state of Rajasthan, 60 per cent and in Kerala 85 per cent of all COVID-19 patients, after 1 May 2020, have been found as migrants who returned from cities (Sharma, 2020). The increasing cases of COVID-19 in rural India are highly devastating on already dilapidated health facilities and the inadequate number of doctors in rural areas.

\section{Health Care Infrastructure}

With the increase in COVID-19 infection and resultant deaths, the demand for health infrastructure has also increased. However, the existing health infrastructure and the availability of health professionals are found to be inadequate with respect to the growing need. According to the National Health Profile-2019, India had 25778 hospitals with 713986-bed capacity; of this, 4375 hospitals are in urban areas with 448711 beds until 1 January, 2018 (GOI, 2019). The number of hospital beds in India per 1000 population is just 0.55 , which is far behind China (4.3), Italy (3.2) and the US (2.8) (Bhaduri, 2020). The number of allopathic doctors (116757) and nurses (8,60,927 ANM) in the country (GOI, 2019), which are also far less than the recommended Doctor-Patient ratio of 1:1000 by WHO. In the present condition, there is one doctor for every 1,445 Indians as per the country's 1.35 billion population in 2019 (Business Standard, 2019) that accounts for 0.857 doctors per 1000 population (World Bank, 2018) which is also lower than Italy (4 doctors), Spain (3.9 doctors), United States (2.9 doctors) and China ( 2 doctors) (Niall, 2020). In critical cases of COVID-19, intensive care is needed, and India has just 95 thousand ICU beds including both public and private sector hospitals, while 50 per cent (48000) of all ICU beds may have ventilators (Kapoor et al., 2020; Singh et al., 2020). In April itself, nearly 40 days after the SARS-CoV-2 hit Mumbai city, the health infrastructure started crumbling as the city which had just 1900 isolation beds and nearly 200 ICU beds (Shelar, 2020). In a study, titled 'Estimating the global spread of COVID-19', by the MIT's Sloan School of Management researchers Hazhir Rahmandad, TY Lim and John Sterman have predicted that India may record the highest number of fresh COVID-19 cases in the world by the end of winter in 2021 with 2.87 lakh cases per day (The Indian Express, 2020). According to the Ministry of Health and Family Welfare, there are 32,362 ICU beds in total in the country dedicated for COVID-19 patients apart from 1,20,104 oxygen supported beds and 8,91,828 isolation beds (The New Indian Express, 2020). However, despite the economic growth in the last two and half decades, the poor condition of health infrastructures prior to the emergence of the pandemic, show less prioritized public health ecosystem in India. The share of India's GDP expenditure was just 1.28 percent in 201718 , which is far behind many developing countries (Dutta, 2020). The rapid influx of COVID-19 patients along with routine patient needs rapid expansion of current capacity or modifications in admission policy for health care to all.

\section{Conclusion}

Urbanisation pattern is one of the massive planning and policy challenges in recent decades. The expansion as well as densification of cities, mainly the mega-urban agglomerations, with a large share of the unskilled workforce from rural areas has intensified the public health challenges amid COVID-19 pandemic. In the present crisis of COVID-19, the various urban characteristics are found to increase the vulnerability of COVID-19 spread. The urban population density expanded urban areas, and associated intra-urban commuting, slum residence and problems of water, sanitation, and housing have triggered the spread of COVID-19 in urban India. In the situation of unavailability of water in housing premises, inadequate toilet facilities and substandard housing conditions, adherence to the measures of home quarantines, social distancing, regular hand washing and other hygiene measures would be certainly difficult 
and the spread may further increase and may recur in the same areas if inefficiently responded. The Central and State Governments have made efforts to contain to the virus, and indeed, the spread has been restricted. Rapid enhancement in health infrastructure has been made and over 1 million tests per day are being made on 1 September 2020 at 1631 testing centres across the country. The strict adherence to measures of quarantine, social distancing and hygiene by the citizens at large has been crucial in our fight against COVID-19. However, the increase of over 70 thousands cases of illness per day in August has inflamed the challenge to infiltrate the spread in the new areas and minimising in the containment zones. There are several lessons for the urban regulatory bodies to plan the future urban cities which can mitigate the environmental problems as well as tackle such pathogens.

\section{References}

Acuto, M. (2020). COVID-19: Lessons for an Urban(izing) World. One Earth, 2 (4), pp. 317319.

http://doi.org/10.1016/j.oneear.2020.04.2020.

Ali Q. S. W. \& Dkhar N. B. (2018, December

28). India's rampant urban water issues and challenges. The energy and resource institute. Retrieved 6 June 2020 from, https://www.teriin.org/article/indias-rampanturban-water-issues-and-challenges

Barr, J. and Tassier T. (2020, April 17). Are Crowded Cities the Reason for the COVID-19 Pandemic? Placing too much blame on urban density is a mistake. Observations. Retrieved 26 May 2020

from,https://blogs.scientificamerican.com/obse rvations/are-crowded-cities-the-reason-for-thecovid-19-pandemic/

Bhaduri, S. D. (2020, March 19). What India can learn from China and South Korea to ward off coronavirus. Retrieved 27 May 2020 from, https://economictimes.indiatimes.com/

Biswas, P. P. (2020). Skewed Urbanisation and the Contagion. Economic and Political Weekly, 55(16).
Business Standard (2019, November 19). India's doctor-patient ratio still behind WHOprescribed 1:1,000: Govt. Retrieved 29 May 2020 from, https://www.business-

standard.com

Covid19india.org. (2020). Coronavirus Outbreak in India. Retrieved 3 July \& 03 September 2020 from, https://www.covid19india.org/

Dandekar, A. (2020). Migration and Reverse Migration in the Age of COVID-19. Economic and Political Weekly, 55(19).

Daszak, P., Cunningham A. A., \& Hyatt A. D., (2000). Emerging infectious diseases of wildlife - threats to biodiversity and human health. Science, 287, 443-449.

Desai D. (2020). Urban Densities and the Covid19 Pandemic: Upending the Sustainability Myth of Global Megacities. ORF Occasional Paper.

Retrieved 03 June 2020 from, https://www.orfonline.org/wpcontent/uploads/ 2020/05/ORF_OccasionalPaper_244_Pandemic UrbanDensities.pdf

Dutta, S. S. (2020, June 12). India may run out of ICU beds for COVID-19 patients by July end:

Study. The New Indian Express. Retrieved 20 June 2020

from,https://www.newindianexpress.com/natio $\mathrm{n} / 2020 / j u n / 12 /$ india-may-run-out-of-icu-bedsfor-covid-19-patients-by-july-end-study2155757.html

Elzy Kolb (2019, July 11). 75,000 people per square mile? These are the most densely populated cities in the world, 24/7 Wall Street. Retrieved 26 May 2020 from, https://www.usatoday.com

Eubank, S., Kumar G. H., Anil V. et al. (2004). Modelling disease outbreaks in realistic urban social networks. Nature, 429, 180-184. https://doi.org/10.1038/nature02541

Gani S. R., Ali, S. T. \& Kadi, A. S. (2011). The transmission dynamics of pandemic influenza A/ H1N1 2009-2010 in India, Current Science, 101(8). pp. 1065-1072.

Government of India (2011). Data on Workers (B-Series), Office of the Registrar General \& 
Census Commissioner, India, Government of India, New Delhi.

Government of India (2011). Migration Tables (D-Series), Office of the Registrar General \& Census Commissioner, India, Government of India, New Delhi.

Government of India (2011). Primary Census Abstract, Office of the Registrar General \& Census Commissioner, India, Government of India, New Delhi.

Government of India (2014). Urban Slums in India, 2012. NSS 69th Round, National Sample Survey Office, Ministry of Statistics and Programme Implementation, Government of India, New Delhi.

Government of India (2019). National Health Profile-2019. Central Bureau of Health Intelligence, Directorate General of Health Services Ministry of Health \& Family Welfare, New Delhi.

Guttikunda, S. K. \& Mohan D. (2014). Re-fueling road transport for better air quality in India. Energy Policy, 68, pp. 556-561.

Hindustan Times (2020, April, 30). Inside Dharavi: India's largest slum and a major Covid hotspot. https://www.hindustantimes.com

Hotez, P. J. (2017). Global urbanisation and the neglected tropical diseases. PLoSNegl Trop Dis, 11(2). Retrieved 16 May 2020 from,https://doi.org/10.1371/journal.pntd.000 5308.

Jena, M. (2017, November 18). Urban India's paradox: The homeless risk death daily on the streets even as shelters remain empty.

Retrieved 20 May 2020 from, https://scroll.in/article

Jha, R. (2020). Urbanisation of pandemics. Observer Research Foundation. Retrieved 16 May 2020

from,https://www.orfonline.org/expertspeak/urbanisation-pandemics-65512/

Joel K. (2020, April 2). After coronavirus, we need to rethink densely populated cities. Fortune. Retrieved 29 April 2020 from, https://fortune.com/2020/04/01/coronavirusdense-cities-urban-rural/

Jonathan C. (2017). Urbanisation, Growth, and Development: Evidence from India, World Bank, Washington, DC. Retrieved 26 May 2020 from, https://www.gov.uk

Jones, K. E., Patel, N. G., Levy, M. A., Storeygard, A., Balck, D., Gittleman J. L., \& Daszak P. (2008). Global Trends in Emerging Infectious Diseases. Nature, 451(21), pp. 990-994. https://doi.org/10.1038/nature06536 Kapoor, G., Sriram, A., Joshi, J., Nandi, A. \& Laxminarayan R. (2020, April 21). COVID-19 in India: State-Wise Estimates of Current Hospital Beds, ICU Beds, and Ventilators. Retrieved 25 May 2020 from, https://cddep.org

Kumar S. \& Quinn S. C. (2012). Existing health inequalities in India: informing preparedness planning for an influenza pandemic, Health Policy and Planning, 27(6), p. 516.

McLafferty, S. (2010). Placing pandemics: Geographical dimensions of vulnerability and spread. Eurasian Geography and Economics, 51. Retrieved 25 May 2020 from, https://doi.org/10.2747/1539-7216.51.2.143

Mitra, R. (2020 March, 23). Over 1.7 million homeless residents across India struggle to fight coronavirus. The New Indian Express. Retrieved 25 May 2020 from,https://www.newindianexpress.com Morens, D. M., Folkers G. K. \& Fauci A. S. (2004). The Challenge of Emerging and Reemerging Infectious Diseases. Nature, 430, 242249. https://doi.org/10.1038/nature02759

National Sample Survey Organisation (NSSO) (2012). Employment, Unemployment and Migration Survey, July 2007 - June 2008. Ministry of Statistics and Programme Implementation, Government of India (GOI), New Delhi.

Neiderud C. J. (2015). How urbanisation affects the epidemiology of emerging infectious diseases. Infection Ecology \& Epidemiology, 5(1). Retrieved 16 May 2020 from, https://doi.org/10.3402/iee.v5.27060 
Niall M. (2020, March 19). The Countries With The Highest Density of Doctors, Statista.

Retrieved 16 May 2020 from, https://www.statista.com.

Nova, C. (2020). Covid-19 and the water crisis in India: a wakeup call for clean water. Smart water magazines, Retrieved 26 May 2020 from,https://smartwatermagazine.com Patidar, H. (2018). Livelihood Security in Rural India: Reflections from Some Selected Indicators. Forum for Development Studies, 46 (1).

https://doi.org/10.1080/08039410.2018.15195 17.

Pradhan, K. C. (2013). Unacknowledged urbanisation: The new Census towns of India, MPRA Working Paper, Centre for Policy Research, New Delhi. Retrieved 16 May 2020 from,https://mpra.ub.uni-muenchen.de/41035/

Rocklöv, J. and Sjödin H. (2020). High population densities catalyze the spread of COVID-19. Journal of Travel Medicine, 27(3). https://doi.org/10.1093/jtm/taaa038.

Ruiqi L., Richmond P. \& Roehner B. M. (2018). Effect of population density on epidemics. Physica A: Statistical Mechanics and Its Application, 510, pp. 713-724. https://doi.org/10.1016/j.physa.2018.07.025

Shaikh, Z. \& Singh, L. (2019, July 22). The street is their home. Retrieved 15 June 2020 from https://indianexpress.com

Sharma, N. C. (2020, May 28). Rural India is the new covid-19 flashpoint amid migrant influx. Livemint. Retrieved 02 June 2020 from,https://www.livemint.com/news/india/rur al-india-is-the-new-covid-19-flashpoint-amidmigrant-influx-11590608606400.html

Shelar, J. (2020, April 16). Coronavirus: Mumbai runs out of beds in ICUs, patients suffer, The Hindu. Retrieved 25 May 2020 from,https://www.thehindu.com/news/cities/ mumbai/coronavirus-mumbai-runs-out-ofbeds-in-icus-patientssuffer/article31360363.ece

Singhal, S., Matto M. \& Parsad J. (2020, May 18). COVID-19: Hits \& misses of Centre's advisory on water supply, sanitation: A review of MoHUA April, 2020 advisory on safe management of water supply and sanitation. Retrieved 16 June 2020 from, https://www.downtoearth.org.

Smolinski, M. S., Hamburg, M. A. \& Lederberg J. (2003). Microbial Threats to Health: Emergence, Detection and Response, Washington (DC). National Academies Press (US). Retrieved 16 May 2020

from,https://www.ncbi.nlm.nih.gov/books/NBK 221486/pdf/Bookshelf_NBK221486.pdf

Subbaraman, R., Nolan, L., Shitole, T., Sawant, K., Shitole, S., Sood, K., Nanarkar, M., Ghannam, J., Betancourt, T. S., Bloom, D. E. \& Patil D. A., (2014). The psychological toll of slum living in Mumbai, India: a mixed methods study. Social Science and Medicine, 119. pp. 155-169. https://doi.org/10.1016/j.socscimed.2014.08.02 1

Sundaram N., Schaetti, C. \& Purohit, V. et al. (2014). Cultural epidemiology of pandemic influenza in urban and rural Pune, India: a crosssectional, mixed methods study, BMJ Open, http://dx.doi.org/10.1136/bmjopen-2014006350

The Daily Pao (2016). An exhibition examines the severity of homelessness in Mumbai.

Retrieved 18 May 2020

from,https://www.thedailypao.com

The Indian Express (2020, 9 July). India may become worst-hit, record 2.87 lakh Covid cases daily by 2021: MIT Study. Retrieved 15 September 2020 from, https://indianexpress.com/article/india/indiadaily-covid-coronavirus-cases-mit-study-6495853/

The New Indian Express (2019, November 1). India's public expenditure on health less than lower income countries: Government data. Retrieved 16 May 2020 from,https://www.newindianexpress.com/natio n/2019/nov/01/indias-public-expenditure-onhealth-less-than-lower-income-countriesgovernment-data-2055553.html

UNDP (2014). Our Urbanising World-2014/3, Department of Economic and Social Affairs, Population Division. https://www.un.org 
Unger, A., Riley L. W. (2007). Slum health: from understanding to action. PLoS Medicine, 4, pp. 1561-66.

https://doi.org/10.1371/journal.pmed.0040295

Un-Habitat (2003). The Challenge of slums:

Global Report on Human Settlements, United Nations Human Settlements Programme.

Earthscan Publications Ltd London and Sterling, VA. Retrieved 26 May 2020

from,https://www.un.org/ruleoflaw/files/Challe nge\%20of\%20Slums.pdf

United Nations (2018). The World's Cities in 2018. Economic and Social Affairs, United Nations. Retrieved 16 June 2020 from, https://www.un.org

United Nations General Assembly (2010, July 28). Resolution 64/292: The human right to water and sanitation. Retrieved 16 May 2020 from, https://www.un.org/en/ga/64/resolutions.shtm I.

United Nations, (2019). World Population Prospects 2019: Data Booklet (ST/ESA/SER.A/424), Department of Economic and Social Affairs, Population Division, United Nations. Retrieved 20 June 2020 from,https://population.un.org/wpp/Publicatio ns/Files/WPP2019_DataBooklet.pdf

United Nations, Department of Economic and Social Affairs, Population Division (2019). World Population Prospects 2019: Data Booklet (ST/ESA/SER.A/424). Retrieved 15 September 2020 from, https://population.un.org/wpp/Publications/Fil es/WPP2019_DataBooklet.pdf

Weiss, R. A. \& McMichael A. J. (2004). Social and environmental risk factors in the emergence of infectious diseases. Nature Med, 10, S70-S76. https://doi.org/10.1038/nm1150

Word Bank (2018). Word Bank Data. Retrieved 16 June 2020 from https://data.worldbank.org

World Bank (2020). Urban Development. Urban development overview. Retrieved 16 June 2020 from,

http://www.worlbank.org/en/topic/urbandevel opment/overview.
World Health Organisation (2011). How much water is needed in emergencies, Technical notes on drinking-water, sanitation and hygiene in emergencies. Retrieved 26 May 2020 from, https://www.who.int/water_sanitation_health/ emergencies/WHO_TN_09_How_much_water_ is_needed.pdf?ua $=1$

World Health Organisation (2020). Corona virus disease (COVID-19) outbreak situation.

Retrieved 2 September 2020 from, https://www.who.int/emergencies/diseases/no vel-coronavirus-

2019?gclid=EAlaIQobChMI60_7kNHv6wIVkqqW Ch0OjwjFEAAYASAAEgKbbfD_BwE

Wratten, E. (1995). Conceptualizing urban poverty. Environment and Urbanisation, 7, 1138.

https://doi.org/10.1177\%2F0956247895007001 18

Xiao W., et al. (2020). Exposure to Air Pollution and COVID-19 Mortality in the United States, MedRxiv. https://doi.org/10.1101/2020.04.05.20054502

Yashima K. \& Sasaki A (2014). Epidemic Process over the Commute Network in a Metropolitan Area. PLOS ONE, 9(6), e98518.

https://doi.org/10.1371/journal.pone.0098518.

Zachreson C., Fair, K. M., Cliff, O. M., Harding, N., Piraveenan, M. \& Prokopenko M. (2018). Urbanisation affects peak timing, prevalence, and bimodality of influenza pandemics in Australia: Results of a census-calibrated model. Science Advances, 4.

http://advances.sciencemag.org

\section{Conflict of Interest}

We confirm that we do not have any potential conflict of interest at a personal level, any financial and other relationship with our own institute or any other organisation which may influence our or their work.

\section{Acknowledgements}

The authors are grateful to the two anonymous reviewers for the careful reading of our manuscript and their insightful comments and suggestions which have been significant in improving the manuscript of the paper. 
Author Contribution Statement

While the first author did conceptualisation, designing of the study as well as data curation and drafting of original work; both the authors reviewed and edited the final draft. 